\title{
Article \\ The Benefit of Continuous Hydrological Modelling for Drought Hazard Assessment in Small and Coastal Ungauged Basins: A Case Study in Southern Italy
}

\author{
Davide Luciano De Luca $^{1}$ (D), Ciro Apollonio ${ }^{2, *(D)}$ and Andrea Petroselli ${ }^{3}$ (D) \\ 1 Department of Informatics, Modelling, Electronics and System Engineering, University of Calabria, \\ 87036 Rende, Italy; davide.deluca@unical.it \\ 2 Department of Agriculture and Forest Sciences (DAFNE), Tuscia University, 01100 Viterbo, Italy \\ 3 Department of Economics, Engineering, Society and Business Organization (DEIM), Tuscia University, \\ 01100 Viterbo, Italy; petro@unitus.it \\ * Correspondence: ciro.apollonio@unitus.it
}

check for

updates

Citation: De Luca, D.L.; Apollonio,

C.; Petroselli, A. The Benefit of

Continuous Hydrological Modelling for Drought Hazard Assessment in

Small and Coastal Ungauged Basins: A Case Study in Southern Italy.

Climate 2022, 10, 34. https://

doi.org/10.3390/cli10030034

Academic Editors: Heejun Chang

and Salvatore Magazù

Received: 13 January 2022

Accepted: 1 March 2022

Published: 3 March 2022

Publisher's Note: MDPI stays neutral with regard to jurisdictional claims in published maps and institutional affiliations.

Copyright: (c) 2022 by the authors. Licensee MDPI, Basel, Switzerland. This article is an open access article distributed under the terms and conditions of the Creative Commons Attribution (CC BY) license (https:// creativecommons.org/licenses/by/ $4.0 /)$.

\begin{abstract}
Rainfall-runoff modelling in small and ungauged basins represents one of the most common practices in hydrology. However, it remains a challenging task for researchers and practitioners, in particular in a climate change context and in areas subject to drought risk. When discharge observations are not available, empirical or event-based approaches are commonly used. However, these schemes can be affected by several relevant assumptions. In the last years, continuous models have been developed in order to address the major drawbacks of event-based approaches. With this goal in mind, in this work we applied a synthetic rainfall generation model (STORAGE; stochastic rainfall generator), constituting the implementation of a modified version of Neymann-Scott rectangular pulse (NSRP) model, and a continuous rainfall-runoff framework (COSMO4SUB; continuous simulation modelling for small and ungauged basins) specifically designed for ungauged basins within a climate change context. The modeling approach allows one to investigate the drought hazard using specific indicators for rainfall and runoff in a small watershed located in southern Italy. Results show that the investigated area seems to tend to a mild/moderate drought in a future time period of approximately 30 years, with a decrease in seasonal water volumes availability in the range of $15-30 \%$. Finally, our results confirm that the continuous modelling is suitable for rapid and effective design simulations supporting drought hazard assessment.
\end{abstract}

Keywords: climate change; coastal ungauged basin; COSMO4SUB; drought hazard assessment; hydrological continuous modelling; STORAGE

\section{Introduction}

Global climate change has had a growing impact on water resources management and drought hazard assessment, and the world population has paid the cost of meteorological hazards $[1,2]$.

In 2015, the United Nations encouraged economic, environmental, and social advancements in order to obtain a sustainable future for the entire world population (in particular in a climate change context), introducing the Sustainable Development Goals (SDGs) [3]. Integrated water resources management is part of the SDGs, but today only $2.5 \%$ of all water on Earth can be used for human domestic needs [4]. This aspect as increased researcher and practitioners' interest on water scarcity and droughts.

From several studies, it appears evident that is not possible to provide a unique drought definition since this is related to hydro-meteorological conditions, geographical locations, and water demands in different regions around the world [5]. Hence, the drought definition can be classified using four categories [6,7]: meteorological [8-12], hydrological [13,14], agricultural [15], and socio-economic [16]. The first three categories 
provide direct methods to quantify drought as a physical phenomenon, while the last one measures its direct effect on the social production and on the human life.

The complexity of the processes related to drought makes difficult the identification of a unique diagnostic criterion, which should be able to define the status and trend of the phenomenon. Among the various methods developed by the scientific community, the application of suitable "indicators" seems to have an undoubted usefulness. Particularly interesting is the streamflow drought index (SDI) method, used to predict the drought onset and its duration. This method uses the cumulative flow rate of the river as well as the spatial extent of drought for assessing and monitoring the hydrological droughts [17]. When it is possible to integrate rainfall and vegetation data, it seems more appropriate to use the normalised difference vegetation index (NDVI) and standard precipitation index (SPI) [18]. Also, the Palmer drought severity index (PDSI) has been largely used when temperature and precipitation data are available. However, monthly PDSI values do not capture droughts on time scales lower than 12 months [19].

Focusing in the Mediterranean area, it is not easy to select, develop, and apply indicators to assess the drought hazard, since the region is particularly vulnerable due to climatic and geomorphological conditions and to consolidated anthropic pressure. In this context, desertification research projects such as MEDALUS can be particularly important, aiming to implement 'Plans National Action', referred to the ESAs model (environmental sensitive areas to desertification) $[20,21]$. MEDALUS provided a methodology to standardize all possible indicators in order to identify and discriminate regions at high risk of desertification in the Mediterranean area. In detail, in the MEDALUS model, the vulnerability is substantially connected to climatic, morphodynamic, pedological, vegetational, and anthropic factors. This method was widely applied to several case studies in northern Africa, in the Middle East, and in other Mediterranean-type ecosystems [22]. In Italy, a long-time interval study of vulnerable land growth has been conducted using the ESA approach [23]. The ESA output, called ESAI (environmental sensitivity area index), is an indicator system which examines more than 10 variables assessing climate, soil, vegetation, and intensity in land use [24].

Essentially, the main problem in defining indicators is the need for a robust time series [25-27]. In particular, the World Meteorological Organization (WMO) suggested to consider at least 30 years of continuous rainfall data related to the resolution of interest for specific applications [26]. Such a circumstance is not easy to obtain in small and ungauged basins [28,29], making the estimation of runoff consequent to rainfall difficult [30-32]. In this context, the use of stochastic rainfall generators (SRGs) could help in the analysis of rainfall processes [33]. A SRG generally presents a simple mathematical formulation and low computational costs, and it can be easily used for simulating long rainfall time series by assuming any selected climate change scenario (or eventually in a stationary context).

Moreover, the availability of a long rainfall time series could allow one to apply a continuous rainfall-runoff transformation, and consequently to obtain the whole runoff time series for the selected basin. In doing so, we could have available a design simulation, allowing the robust estimation of drought characteristics and indexes.

The aim of the manuscript is hence to demonstrate the importance of continuous hydrological modelling for the drought hazard assessment in ungauged basins. In order to do that, in this work we first applied two recently developed hydrological models. The former is a synthetic rainfall generation model (STORAGE) [34,35] that was applied in a climate change scenario. The latter is a continuous rainfall-runoff model (COSMO4SUB) [36-38]. After that, we examined several hydrological drought indices based on the modelled rainfall and runoff time series in order to provide an in-depth analysis for a small basin located in southern Italy (Apulia region) that is potentially subject to drought. This approach, never used in the selected study area, represents an important novelty. In fact, the Apulia region unfortunately has a scarce availability of runoff data, making any type of hydrological study complicated. The present manuscript is organized as follows. In Section 2, the materials and methods are described. In particular, the selected case study, the proposed SRG, the 
continuous rainfall-runoff model, and the selected indicators are descripted. In Section 3, our results are presented and discussed. In Section 4, the conclusions are reported.

\section{Materials and Methods}

\subsection{Case Study Description}

The study area pertains to the hydrographic basin of the Cillarese river (Figure 1), a torrential watercourse which has historically represented a fundamental element for the socio-economic development of the area. In particular, the area is included within the municipalities of Oria, Torre Santa Susanna, Latiano, Mesagne and Brindisi, and belongs to the province of Brindisi, in the Salento peninsula, a large area in the southern part of the Apulia region (southern Italy). This region is historically prone both to flooding and to drought [39-41], and one of the known major problems of the area is the overexploitation of the groundwater [42-44]. The analyzed river originates in the municipal territory of Torre Santa Susanna at $103 \mathrm{~m}$ above sea level, and extends for about $28 \mathrm{~km}$ until it reaches the harbor of Brindisi city in the Adriatic Sea.

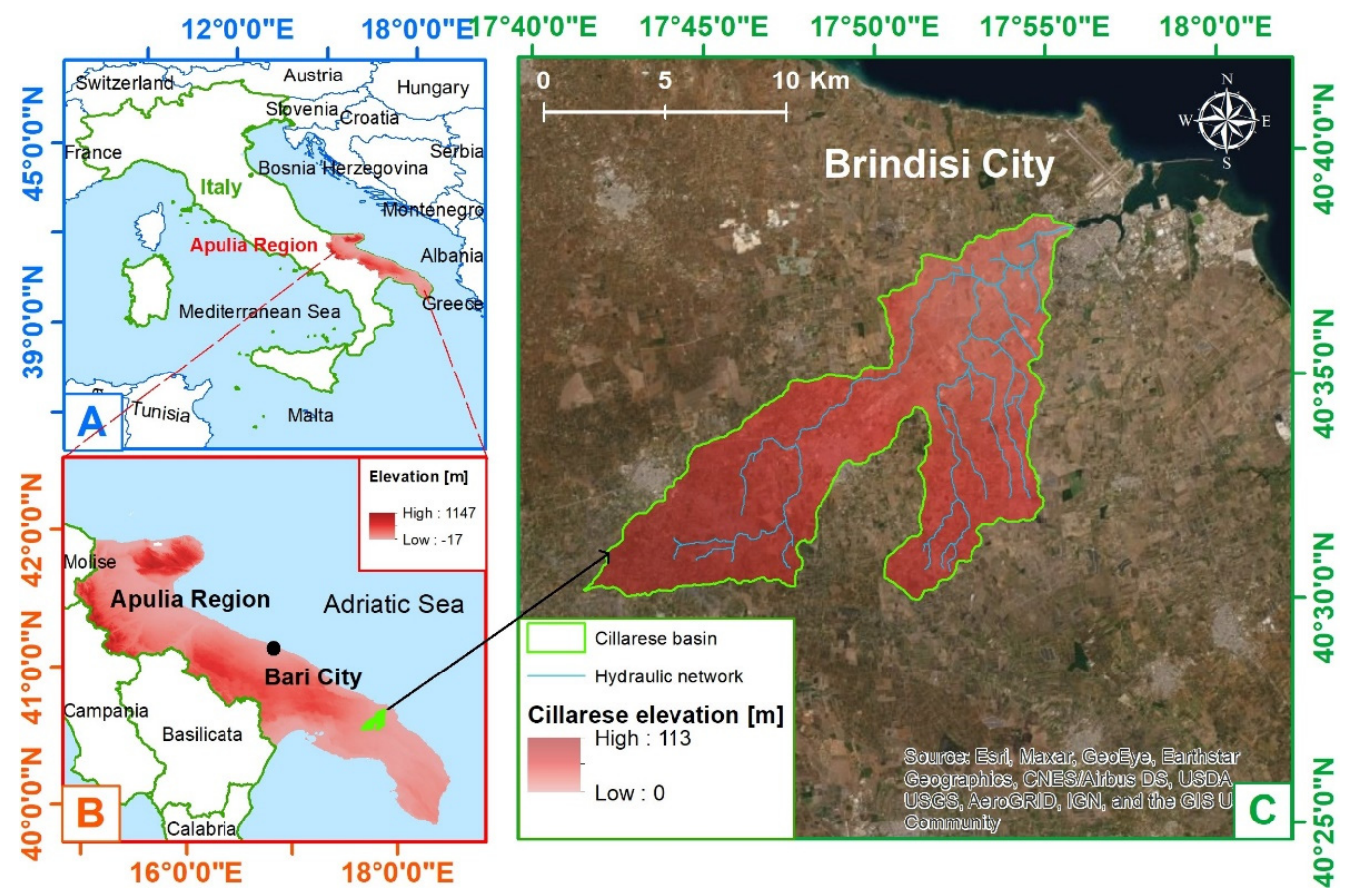

Figure 1. Study area description. (A,B) Geographical identification of Cillarese river basin; (C) digital elevation model (DEM) of analyzed river basin.

In 1980, a dam was built and the course of the Cillarese river in the bottom valley was blocked, allowing for the formation of a water reservoir of over 4 million $\mathrm{m}^{3}$ (with a surface area equal to $2.76 \mathrm{~km}^{2}$ ) for the water supply of the Brindisi industrial development area.

Selecting the dam location as the outlet river cross section, the Cillarese hydrographic basin is characterized by an extension of about $132 \mathrm{~km}^{2}$ and an average slope of $1.3 \%$.

Following the construction of the reservoir on the Cillarese river, a fauna protection oasis (extension equal to $1.27 \mathrm{~km}^{2}$ ) was implemented [45]. Furthermore, the area is classified as SIR (Site of Regional Interest n. IT9140012), in compliance with the European Commission Habitats Directive-92/43/EEC [46]. Based on the ESAI, the area is classified at maximum risk of desertification (category C3-ESAI > 1.53) and, therefore, is among the protected areas of the Apulia Region [47]. These data are confirmed by the Apulia Region River Basin Authority that declared that, on average, the whole Apulia region accounts for only $500 \mathrm{~mm}$ of rainfall with 60-80 wet days per year (in Italy, a day is defined as wet if the daily rainfall depth is equal or greater than $1 \mathrm{~mm}$ ) [48]. 
Concerning the available rainfall data, the rain gauge located in Brindisi $(10 \mathrm{~km}$ far from the catchment's centroid) was considered as representative for the Cillarese basin. The time series of annual maximum rainfall (AMR) for durations equal to 1,3,6,12, and $24 \mathrm{~h}$ (observation period: 1936-2019), and daily data (observation period: 1950-2019) are available and were used for calibration of the adopted synthetic rainfall generator. Data were provided by Apulia Region Civil Protection.

For the selected case study, the rainfall data present a mean annual precipitation (MAP) of $612 \mathrm{~mm}$ and a mean annual number of wet days equal to 69. Concerning mean values of seasonal precipitation, we have $203 \mathrm{~mm}$ for December-January-February (DJF), $134 \mathrm{~mm}$ for March-April-May (MAM), $60 \mathrm{~mm}$ for June-July-August (JJA), and $215 \mathrm{~mm}$ for September-October-November (SON).

\subsection{The Synthetic Rainfall Generation Model}

In this study the synthetic rainfall generator implemented in STORAGE software [34,35] has been used. In detail, the model constitutes a modified version of the Neyman-Scott Rectangular Pulses (NSRP) model [49,50]. In the basic version of the NSRP model, five quantities, which are considered as random variables (and hence follow assigned probability distributions) play a crucial role:

- The waiting time (assumed as exponentially distributed) between the occurrences of two consecutive storms;

- The number of rain cells (also named as bursts or pulses) in each storm. This quantity is considered as a geometric random variable;

- The waiting time (assumed as exponentially distributed) between the occurrences of a storm and of an associated cell;

- The intensity and the duration (both considered as exponentially distributed) of each cell inside a storm.

STORAGE is characterized by two main innovations as respect to the usual NSRP model described in literature. First, the parametric estimation is carried out by using data series (i.e., annual maxima rainfall, annual and monthly cumulative rainfall, annual number of wet days) which are usually longer than observed high-resolution series (which are commonly used for the calibration of a usual NSRP model). Second, the seasonality is modelled using series of goniometric (i.e., sine and cosine) functions. This approach makes STORAGE less demanding, in terms of the total needed number of parameters, as it usually occurs for basic versions of NSRP models.

In this work, a transient version of STORAGE was adopted [34], in which some parameter trends are assumed (see Section 3) on the basis of the available projections of regional climate models (RCMs) for the investigated area, in order to obtain a highresolution synthetic rainfall time series which respects the trends hypothesized by RCMs at coarser scales. The hypothesis that the statistics of a really-averaged rainfall simulated by climate models reflect changes at the point rain gauge scale is commonly used in literature [34].

In detail, the publication of the Italian Institute for Environmental Protection and Research (ISPRA) [51] considered four RCMs (ALADIN52, CMCC-CCLM4, GUF-CCLM4, and LMDZ4), and for each one we have two scenarios of representative concentration pathways (RCP) of total radiative forcing (i.e., the cumulative measure of human emissions of greenhouse gasses from all sources expressed in $\mathrm{W} / \mathrm{m}^{2}$ ): RCP $4.5 \mathrm{~W} / \mathrm{m}^{2}$ (intermediate emissions) and RCP $8.5 \mathrm{~W} / \mathrm{m}^{2}$ (high emissions). With respect to the reference period 1971-2000, the results of the RCM simulations for the spatial cells comprising Cillarese basin and related to the future period from 2000 to 2070 are:

- A decrease of the annual cumulative precipitation value, which is comprised between -100 and $-50 \mathrm{~mm}$;

- A modest increase (no greater than $5 \mathrm{~mm}$ ) for the annual maximum daily rainfall. 
In detail, the application of STORAGE here performed consisted of the following steps. First, under the hypothesis of stationary process, STORAGE was calibrated according to [35], i.e., by employing the parameters of amount-duration-frequency (ADF) curves, mean values for MAP, mean annual number of wet days, and mean values of DJF, MAM, JJA, and SON rainfall depths.

Second, the stationary version of STORAGE was validated by generating 500-year time series at 5-min resolution and by comparing the synthetic and observed data in terms of frequency distributions for AMR, annual and seasonal rainfall, and annual number of wet days.

Third, the climate change analysis was carried out by assuming some trends for STORAGE parameters, using those that provided compatible results with RCM scenarios in terms of variation for maximum daily rainfall and annual precipitation. In detail, the adopted scenario combines the following hypotheses:

- A linear increasing trend of about $26 \%$ in 50 years concerning the mean waiting time between two consecutive storms;

- A linear increasing trend of about $22 \%$ in 50 years concerning the mean value of intensity of rainfall cells;

- A linear decreasing trend of about $14 \%$ in 50 years concerning the mean value of duration of rainfall cells.

Fourth, 500 synthetic time series, each one concerning 51 years of continuous 5-min rainfall depths, were generated. The first generated year, denoted as " 0 ", has the features of the calibrated stationary process, while the successive years are characterized by the assumed parameter trends. In this case, analysis with multiple realizations is necessary as the process is not assumed as stationary in this step, and then investigation of only one long time series is not possible, since the ergodicity property cannot be considered [52]. The generated 500 rainfall realizations were the input data for the COSMO4SUB input data, and the results have been averaged on the 500 rainfall realizations as explained in the following paragraph.

\subsection{The Continuous Rainfall-Runoff Model}

The continuous rainfall-runoff model used in the present manuscript is the COSMO4SUB framework introduced by Grimaldi et al. [36,37] and recently updated by Grimaldi et al. [38] COSMO4SUB is characterized by four steps: (1) the rainfall scenario definition; (2) the excess rainfall estimation; (3) the excess rainfall-runoff transformation; and (4) the design simulation strategy.

Regarding step (1), the synthetic rainfall time series (generated by STORAGE) were used as input of COSMO4SUB.

Regarding step (2), COSMO4SUB applies the Curve Number (CN) for Green-Ampt (GA)-CN4GA-procedure [53]. CN4GA is a mixed model that first applies the National Resources Conservation Service (NRCS) CN method [54] in order to transform, at the event scale, the gross rainfall cumulative depth in excess rainfall depth (i.e., determining the cumulative infiltration depth), and then uses the GA equation [55] to distribute in time, within the rainfall event, the excess rainfall. The GA equation parameters are automatically estimated by CN4GA constraining the GA equation to furnish the same total excess rainfall depth and the same ponding time equal to that estimated by the $\mathrm{CN}$ method. It is noteworthy that, in order to adapt at the continuous modelling approach, the CN4GA procedure that was originally developed at event scale (i.e., a sort of rainfall event identification named separation time, Ts) is needed. Basically, the separation time represents the dry (or almost dry) period that should be spent waiting so that the soil initial abstraction became effective again. In detail, model parameters inherent to this step are essentially $\mathrm{CN}$ (which can vary from 0, i.e., all rainfall becomes infiltration and no runoff is formed, to 100 (i.e., all rainfall becomes runoff and no infiltration is allowed)), which can be estimated based on land cover and soil type, and Ts, which must be assigned by user. In the present work, following the suggestions of Grimaldi et al. [38], we considered $24 \mathrm{~h}$ as value for Ts, while 
$\mathrm{CN}$ was estimated as 70.4 in AMC-II condition (i.e., in soil moisture average condition). Starting from the $\mathrm{CN}$ value in AMC-II condition, and based on the cumulative value of rainfall occurred in the 5 antecedent days period, the $\mathrm{CN}$ value is automatically adjusted by COSMO4SUB for the generic rainfall event assigning a higher or lower value in case of AMC-III (wet soil) or AMC-I (dry soil) condition, according to the original NRCS-CN formulation [54].

Regarding step (3), the width function based instantaneous unit hydrograph (WFIUH) model based on the partial contributing area concept [56] is applied for convoluting excess rainfall into runoff time series. Regarding the WFIUH, this work has used the approach proposed by Petroselli [56], dividing the basin area in two parts. The first part takes into account the basin saturated area, responsible of the basin "fast" response to rainfall (the surface runoff). The second part takes into account the basin unsaturated area, responsible of the basin "slow" response to rainfall (the subsurface runoff). The division of the basin in the two saturated and unsaturated areas (mutually exclusive) is performed following the steps introduced by Petroselli [56] using the topographic wetness index and assuming a percentage of basin saturated area as a function of the cumulative rainfall value (characterizing the single rainfall event in the generated rainfall time series). In doing so, such WFIUH optimizes the available DEM, land cover and soil type information, and it estimates the travel time distribution of watershed DEM cells thanks to: (i) determining automatically the flow paths; (ii) distinguishing between hillslope-channel; and (iii) determining the distributed hillslope surface (in the saturated area) and subsurface (in the unsaturated area) flow velocities based on local slope, land cover, and soil data. Concerning the channel cells, the river network velocity is automatically calibrated assuming that the projection on the time axis of the WFIUH (i.e., its median point) is equal to the basin lag time, which is assumed as the $60 \%$ of the concentration time [54,56]. In this step, the only model parameter is basically Tc, determining the river network velocity, while local slope, land cover, and soil data determine the hillslope cells velocities.

Regarding step (4), and based on what previously expressed, the 500 rainfall realizations generated by STORAGE were fed as input data in COSMO4SUB, allowing one to obtain the corresponding 500 runoff scenarios (each one constituting of 51 years of runoff at 5-min resolution) and to identify the metrics described in the following paragraph.

\subsection{The Investigated Metrics Based on the Generated Rainfall and Runoff Time Series}

Based on the 500 generated rainfall realizations and the consequent 500 runoff time series, the following metrics have been investigated. These indicators have been chosen since they are particularly efficient in individuating environmentally sensitive areas prone to desertification $[20,21]$.

Regarding the rainfall time series, we make reference to some of the metrics present in the European Climate Assessment \& Dataset (https: / /www.ecad.eu/ /indicesextremes / indicesdictionary.php (accessed on 31 January 2022)), and in particular:

- MAP: yearly cumulative precipitation amount (mm);

- WD1: yearly cumulative number of wet days (amount of precipitation greater or equal than $1 \mathrm{~mm}$ ) (days);

- DRYD: yearly cumulative number of dry days (amount of precipitation lower than 1 $\mathrm{mm})$ (days);

- GSTP: yearly cumulative growing season (from April to October) precipitation (mm);

- NGSTP: yearly cumulative non-growing season precipitation (from November to March) (mm);

- DP10: yearly cumulative number of days where the daily precipitation amount is greater or equal than $10 \mathrm{~mm}$ (days);

The previous rainfall metrics have been averaged on the 500 rainfall realizations, each year.

Regarding the runoff time series, we analyze: 
- TNGR: total number of isolated $(\mathrm{Ts}=24 \mathrm{~h})$ rainfall events in the 51 years for each generated rainfall time series (-);

- TNER: total number of isolated excess rainfall events in the 51 years for each generated rainfall time series (-);

- CUMVOL: yearly cumulated volume, averaged on the 500 rainfall realizations $\left(\mathrm{m}^{3}\right)$;

- SDI: streamflow drought index (-), i.e., a well-known index using monthly streamflow values (here averaged on the 500 rainfall realizations) and a process of normalization associated for developing a drought index based upon streamflow data [48]. Literature states that for $\mathrm{SDI}<-2.0$ there is an extreme drought condition, for $-2.0<\mathrm{SDI}<-1.5$ there is a severe drought condition, for $-1.5<\mathrm{SDI}<-1.0$ there is a moderate drought condition, for $-1.0<\mathrm{SDI}<0$ there is a mild drought condition, and for SDI $>0$ there is a non-drought condition;

- FDC: flow duration curves $\left(\mathrm{m}^{3} /\right.$ month). Flow duration curves (here averaged on the 500 rainfall realizations) represent cumulative frequency curves that show the amount of time when specified volumes are equaled or exceeded during a given period.

The analysis of the previously described metrics allows performing an in-depth analysis for the selected case study in terms of drought hazard.

\section{Results and Discussion}

\subsection{Analysis of the Synthetic Rainfall Time Series}

As stated, STORAGE was first calibrated and validated under the hypothesis of stationary process. The results of this first step of rainfall analysis are reported on EV1 (Extreme Value distribution of type 1, also named as Gumbel distribution) probabilistic plots (Figure 2) for AMR series and on Gaussian plots (Figure 3) for the other investigated series. The fitting of the sample distributions can be considered as acceptable, except for 3-h AMR (where we have a marked over-estimation), annual number of wet days (marked under-estimation) and MAM (marked under-estimation).

Then, the transient analysis was carried out by assuming the previously discussed parameters trends. In particular, for each metric it was possible to estimate a trend, as defined in Figure 4, on the time series of 51 years.

The results are illustrated in Figure 4, where six plots show the variability of the six investigated indices. Regarding DRYD, the trend shows that the index is growing, confirming that the study area has a propensity to drought, according also to what indicated by Apulia Region River Basin Authority [48]. For the same reason, it is observed a reduction of the values related to the metrics WD1 and DP10. The obtained results are in line with previous literature studies, which show that in many not-drought regions decreases of dry days and increases of wet days have been observed [57,58].

Regarding the rainfall volumetric metrics, it is interesting to note that the three considered indices (CUMVOL, SDI, FDC) present a decreasing trend. However, the GSTP index, evaluated as yearly cumulative growing season (from April to October) precipitation, shows an almost constant trend, with small fluctuations compared to the average value of the considered time sample. Zhao et al. [59] reported similar GSTP values in a high agricultural drought risk area. In general, also comparing with ecological study based on GSTP [60], our results show an inclination to drought. Analysing the scientific literature, MAP is an indicator largely used to define plant species that could grow and survive in arid and semiarid areas that, in a climate change context, could become drier and warmer. In particular, we can define for MAP a threshold between "low" and "high" MAP environments. Some authors define low-MAP environments the areas characterized by a MAP value lower than $400 \mathrm{~mm}$ [61].

In the present study, MAP is always greater than $500 \mathrm{~mm}$, so the investigated area could not be classified as having high risk of drought. The study of Stuart-Haëntjens et al. [62] predicted forest and grasslands resistance and resilience to extreme drought using a MAP threshold equal to $828 \mathrm{~mm}$. So, we can state that in the investigated area the presence of forests and grasslands would be at risk. However, MAP results showed that the 
annual precipitation decreased during the observed period, confirming some of the results pointed out by Buttafuoco et al. [63] in Southern Italy, and in our opinion confirming that the selected study area is prone to drought risk.
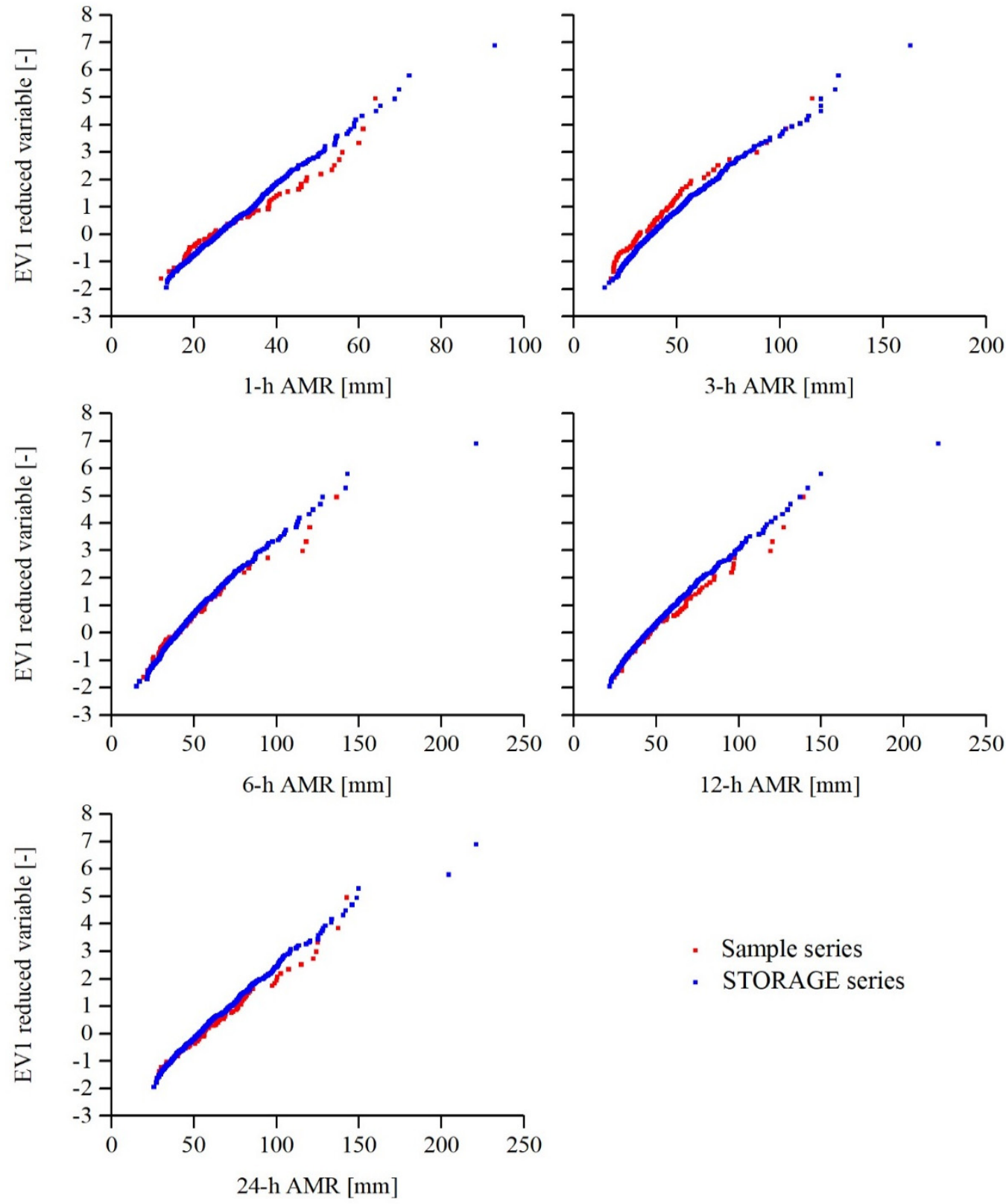

- Sample series

- STORAGE series

Figure 2. Brindisi rain gauge: EV1 (extreme value distribution of type 1, also named as Gumbel distribution) probabilistic plots, showing the comparison among synthetic and observed AMR series, under the hypothesis of stationary process. 

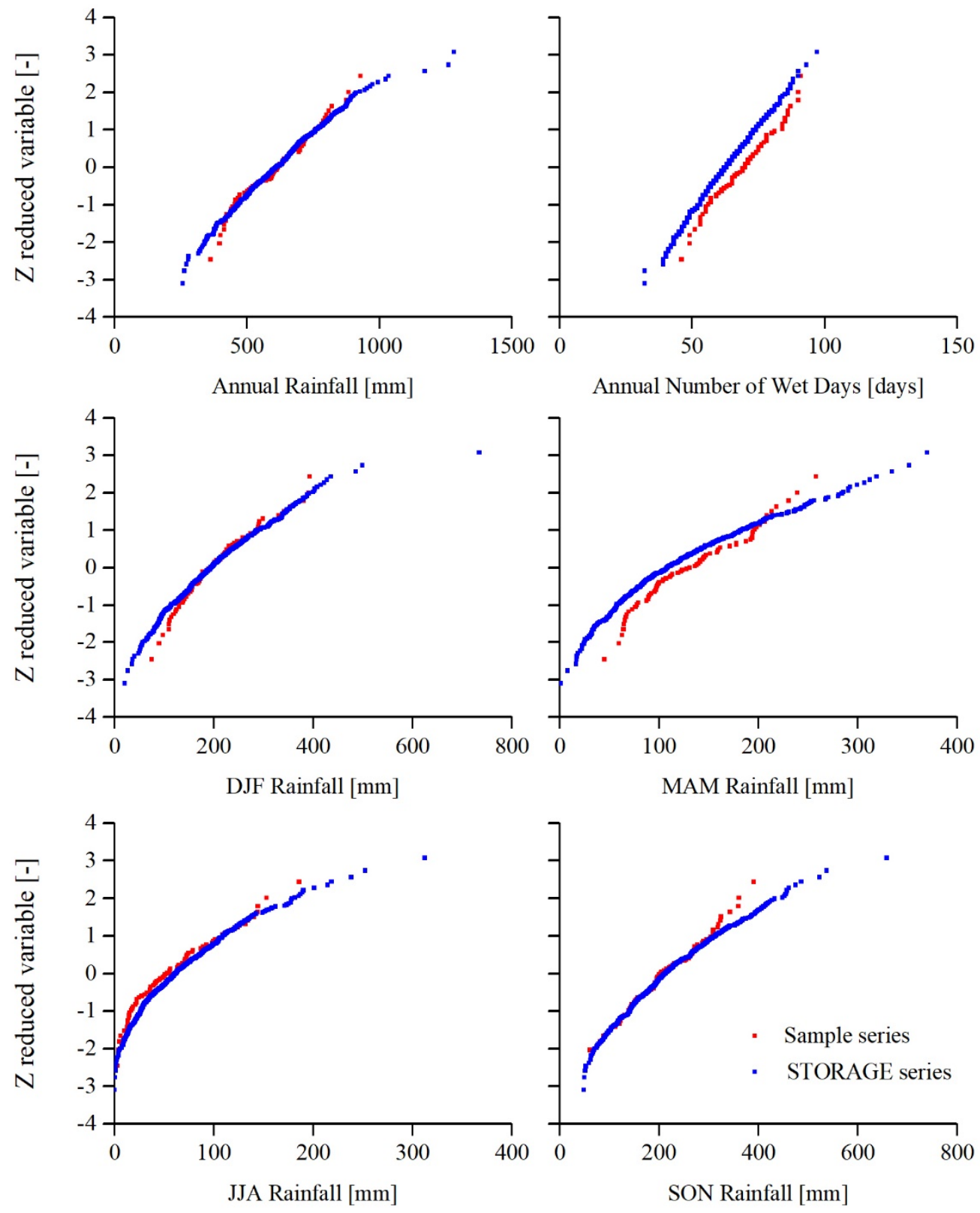

Figure 3. Brindisi rain gauge: Gaussian probabilistic plots, showing the comparison among synthetic and observed series, regarding annual and seasonal rainfall, and annual number of wet days (under the hypothesis of stationary process). 


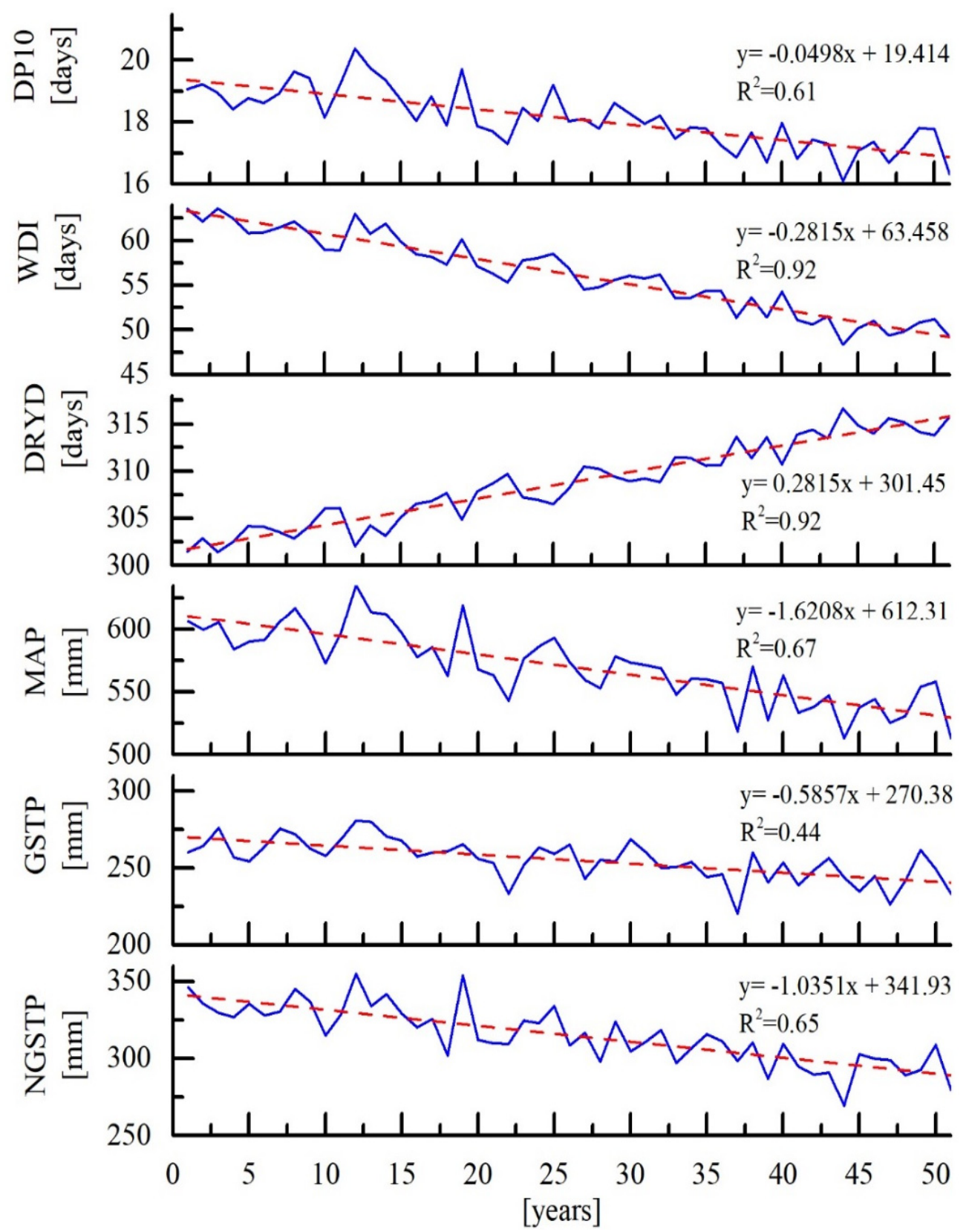

Figure 4. Transient analysis: trend of the investigated rainfall metrics, averaged from 500 STORAGE realizations.

\subsection{Results of the Continuous Rainfall-Runoff Modeling}

Due to the assumed scenario of rainfall change during the years, we show in Figure 5 the total number of isolated rainfall events $(\mathrm{Ts}=24 \mathrm{~h})$ and the corresponding total number of excess rainfall events occurring in the 500 generated rainfall time series. This preliminary analysis shows that the 500 generated rainfall time series present a stable number of rainfall events, which ranges between 2125 and 2425, with an average number of 2304 (i.e., approximately 45 rainfall events each year). Regarding the total number of excess rainfall events, this is mainly due to the study area $\mathrm{CN}$ value, equal to 70.4 in AMC-II condition, but also to the shifts in AMC-I (dry soil) or AMC-III (wet soil) condition that can occur based on the rainfall temporal distribution of the generic rainfall time series realization. 


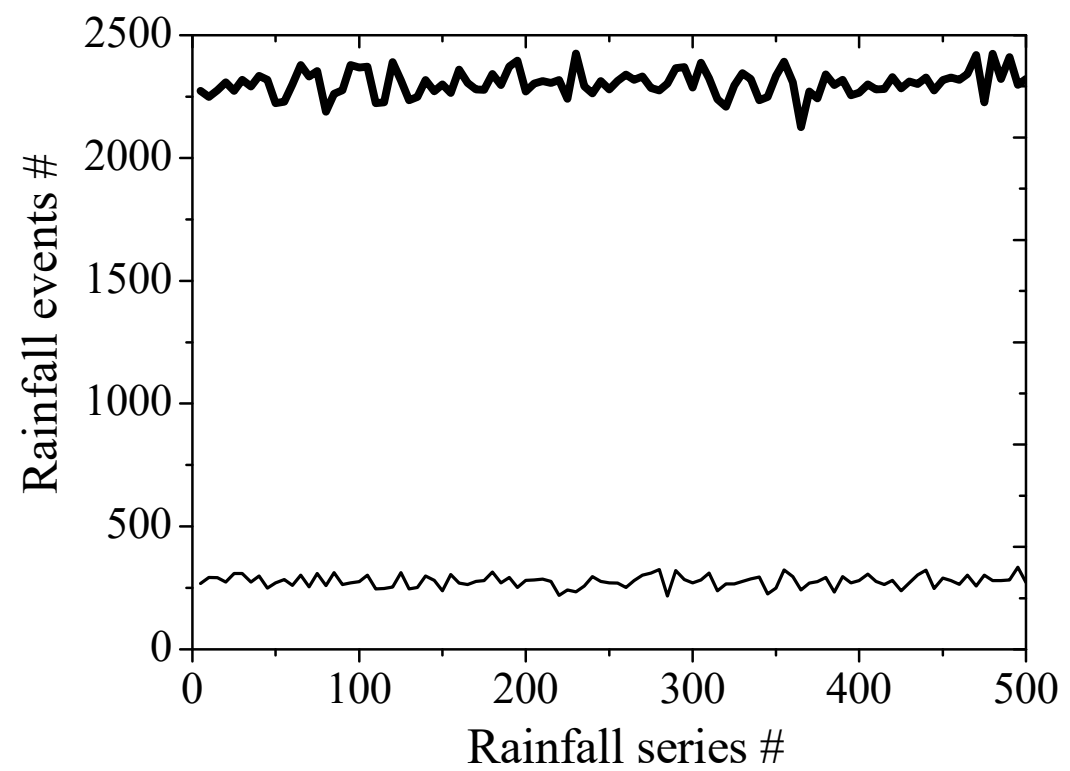

Figure 5. Number of isolated rainfall events in the 500 generated rainfall series. Thick line, rainfall. Thin line, excess rainfall (i.e., rainfall minus infiltration).

As can be seen from Figure 5, the total number of excess rainfall events occurring in the 500 generated rainfall series also present a stable value ranging between 217 and 333 , with an average number of 278 (i.e., approximately 5.4 excess rainfall events each year). Such value could seem a low value, but it can be attributed to the not so high CN value, which allows the majority of rainfall to infiltrate and hence to produce groundwater recharge and baseflow as respect to surface runoff. Indeed, as reported in the regional water protection master plan [47], the study area is characterized by high permeability of the karstic substrate that favors infiltration of rainfall, and there are few surface rivers concentrated in the northern area (Candelaro, Cervaro, Carapelle, and Ofanto). The scarcity of superficial water courses has generated in the past in the Puglia's aquifers important overexploitation (especially by agriculture) [43].

In any case, in our opinion the limited variability within the 500 generated rainfall time series of the total number of rainfall events and excess rainfall events justifies the following analysis of the runoff time series.

Regarding the runoff analysis, in Figure 6 we show the seasonal (DJF, MAM, JJA, SON) time series of the cumulated yearly volumes, averaged on the 500 rainfall realizations. As can be seen from Figure 6, and as expected due to the Italian hydrological regime, the greater number of volumes is concentrated in the DJF and SON period, while the lower amount is related to the summer period, being approximately the $40 \%$ of the volume pertaining to the winter period. Except for the summer period, where the cumulative runoff appears to be quite constant, in the other three seasons we can observe a decrease in the water availability. In particular, in the 50-year time period investigated, the cumulative runoff decreases are approximately 30\% in the DJF season, 33\% in the MAM season, and $15 \%$ in the SON season. 

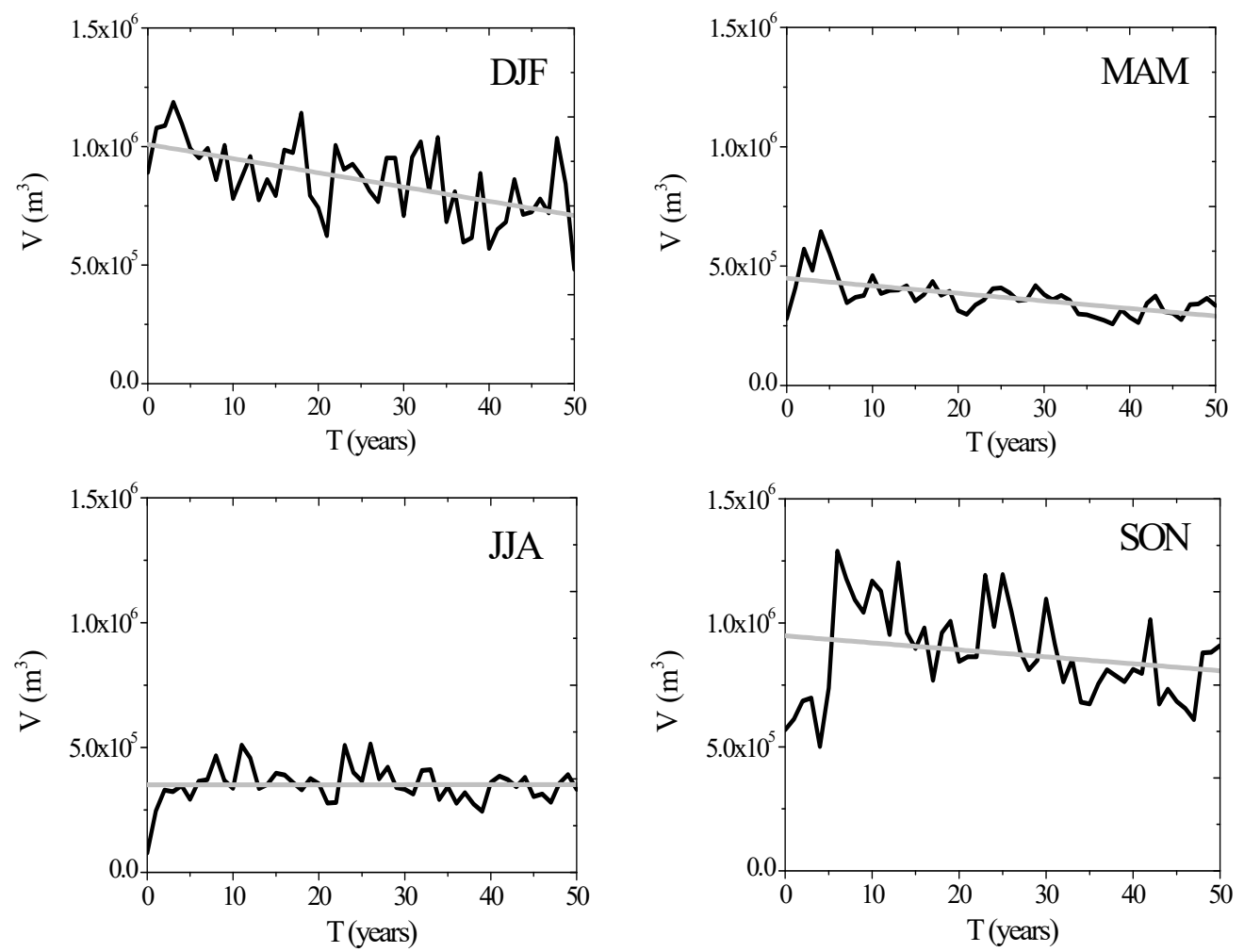

Figure 6. Cumulated seasonal volumes time series (black lines) and linear interpolation (grey lines). Each point is the average of the 500 generated rainfall time series realizations.

In Figure 7 we show the yearly SDI time series, averaged on the 500 rainfall realizations and calculated based on runoff monthly values. As it can be seen from Figure 7, the adopted rainfall scenario tends to generate, in average, a mild drought at the end of the investigated 50 years, but fluctuations in the trend, producing a moderate drought, are visible after approximately 35 years.

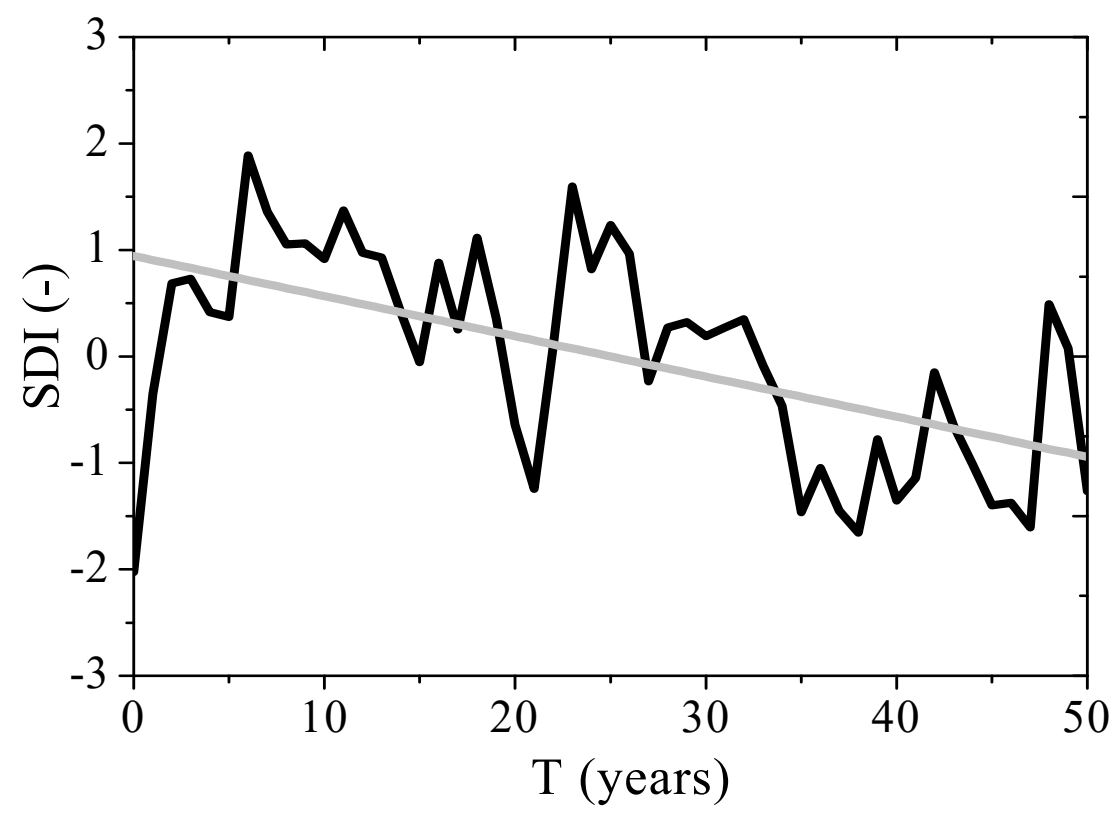

Figure 7. Yearly streamflow drought index time series (black line) and linear interpolation (grey line). Each point is the average of the 500 generated rainfall time series realizations. 
Finally, in Figure 8, we concentrate on the FDC, represented in terms of cumulative runoff that is equaled or exceeded for a certain number of months each year. FDC have been calculated for each year in descending order for the cumulative monthly values of runoff. Then, for each month the 500 realizations are averaged. For the sake of simplicity, in Figure 8, we show the average of the FDC related to the first 10 years and the last 10 years of the investigated period. The decreasing trend in water availability is evident looking from Figure 8, with decreases of approximately $20 \%$ for the first two months and $12 \%$ for the remaining 10 months.

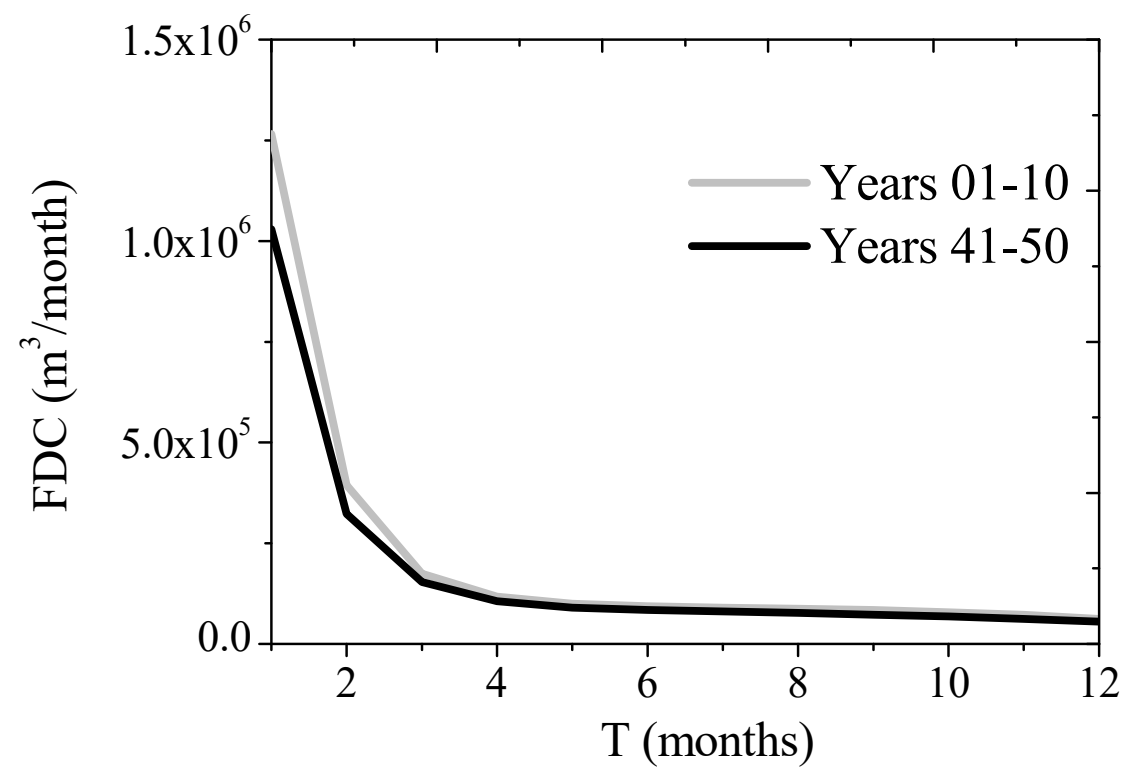

Figure 8. Flow duration curves in terms of cumulated volumes equaled or exceeded for a certain number of months each year. Grey line refers to the average of the years from 01 to 10, while black line refers to the average of the years from 41 to 50 . Each point is the average of the 500 generated rainfall time series realizations, in descending order.

In general, the obtained results are in line with the trends available in the technical literature in the same area. For example, during the 1951-2000 period, total annual precipitation across Puglia region has significantly decreased at a rate of $23.9 \mathrm{~mm} /$ decade, which could lead to a strong reduction of the mean value if this trend would continue for one century more. Generally, long term observations from meteorological stations in the Puglia region show trends towards warmer and drier conditions during the second half of the 20th Century [64]. The trend analysis of considered metrics indicates an increasing drought in the case study area, confirming previous studies $[64,65]$.

\section{Conclusions}

In this paper, a continuous rainfall-runoff modeling is proposed to identify the hydrological response in an ungauged coastal area prone to drought hazard. The methodology consists of two recently developed simple and parsimonious models, namely STORAGE and COSMO4SUB. The first is a synthetic rainfall generation model and the second is a continuous rainfall-runoff model. Projected time series of rainfall and runoff have been analyzed in a climate change context, selecting appropriate metrics for drought analysis. Results show that the investigated area seems to tend to a mild/moderate drought in a time period of approximately 30 years, and that a decrease in water volumes availability in the range $15-30 \%$ can be expected. In conclusion, in our opinion, our results confirm that the continuous modelling approach presented here is suitable for a rapid and effective design simulation supporting drought hazard assessment. The use of STORAGE and COSMO4SUB seems to represent an easy modeling approach that could be employed for evaluating possible measures needed to minimize the impact of drought (for instance, the 
reuse of agricultural wastewaters that is proposed by several researchers [66]) but that today is not so diffused in the Apulia Region [43,67].

Author Contributions: D.L.D.L., C.A. and A.P.: Conceptualization, methodology, software, validation, formal analysis, investigation, data curation, writing-original draft preparation; writingreview and editing. All authors have read and agreed to the published version of the manuscript.

Funding: This research received no external funding.

Institutional Review Board Statement: Not applicable.

Informed Consent Statement: Not applicable.

Data Availability Statement: The data that support the findings of this study are available from the corresponding author, upon request.

Conflicts of Interest: The authors declare no conflict of interest.

\section{References}

1. Du, J.; Fang, J.; Xu, W.; Shi, P. Analysis of dry/wet conditions using the standardized precipitation index and its potential usefulness for drought/flood monitoring in Hunan Province, China. Stoch. Environ. Res. Risk Assess. 2013, 27, 377-387. [CrossRef]

2. Krysanova, V.; Vetter, T.; Hattermann, F. Detection of change in drought frequency in the Elbe basin: Comparison of three methods. Hydrol. Sci. J. 2008, 53, 519-537. [CrossRef]

3. United Nations. Sustainable Development Goals. Available online: https://www.un.org/sustainabledevelopment/sustainabledevelopment-goals / (accessed on 26 March 2021).

4. Yang, T.-H.; Liu, W.-C. A General Overview of the Risk-Reduction Strategies for Floods and Droughts. Sustainability 2020, 12, 2687. [CrossRef]

5. Mishra, A.K.; Singh, V.P. A review of drought concepts. J. Hydrol. 2010, 391, 202-216. [CrossRef]

6. Wilhite, D.A.; Glantz, M.H. Understanding the Drought Phenomenon: The Role of Definitions. Water Int. 1985, 10, 111-120. [CrossRef]

7. American Meteorological Society (AMS). Statement on meteorological drought. Bull. Am. Meteorol. Soc. 2004, 85, 771-773.

8. World Meteorological Organization (WMO). Report on Drought and Countries Affected by Drought during 1974-1985; WMO: Geneva, Switzerland, 1986; p. 118.

9. UN Secretariat General. United Nations Convention to Combat Drought and Desertification in Countries Experiencing Serious Droughts and Desertification, Particularly in Africa; UN Secretariat General: Paris, France, 1994.

10. Haslinger, K.; Blöschl, G. Space-time patterns of meteorological drought events in the European Greater Alpine Region over the past 210 years. Water Resour. Res. 2017, 53, 9807-9823. [CrossRef]

11. Schubert, S.D.; Stewart, R.E.; Wang, H.; Barlow, M.; Berbery, E.H.; Cai, W.; Hoerling, M.P.; Kanikicharta, K.K.; Koster, R.D.; Lyon, B.; et al. Global meteorological drought: A synthesis of current understanding with a focus on SST drivers of precipitation deficits. J. Clim. 2016, 29, 3989-4019. [CrossRef]

12. Huning, L.S.; AghaKouchak, A. Global snow drought hot spots and characteristics. Proc. Natl. Acad. Sci. USA 2020, 117, 19753-19759. [CrossRef]

13. van Loon, A.F. Hydrological drought explained. WIRES Water 2015, 2, 359-392. [CrossRef]

14. Hasan, H.H.; Razali, S.F.M.; Muhammad, N.S.; Ahmad, A. Research Trends of Hydrological Drought: A Systematic Review. Water 2019, 11, 2252. [CrossRef]

15. Liu, Y.; Pan, Z.; Zhuang, Q.; Miralles, D.G.; Teuling, A.J.; Zhang, T.; An, P.; Dong, Z.; Zhang, J.; He, D.; et al. Agriculture intensifies soil moisture decline in Northern China. Sci. Rep. 2015, 5, 11261. [CrossRef] [PubMed]

16. Guo, Y.; Huang, S.; Huang, Q.; Wang, H.; Fang, W.; Yang, Y.; Wang, L. Assessing socioeconomic drought based on an improved Multivariate Standardized Reliability and Resilience Index. J. Hydrol. 2019, 568, 904-918. [CrossRef]

17. Jahangir, M.H.; Yarahmadi, Y. Hydrological drought analyzing and monitoring by using Streamflow Drought Index (SDI) (case study: Lorestan, Iran). Arab. J. Geosci. 2020, 13, 110. [CrossRef]

18. Mlenga, D.H.; Jordaan, A.J.; Mandebvu, B. Integrating standard precipitation index and normalised difference vegetation index for near-real-time drought monitoring in Eswatini. Jamba J. Disaster Risk Stud. 2019, 11, a917. [CrossRef]

19. Dai, A.; National Center for Atmospheric Research Staff (Eds.) The Climate Data Guide: Palmer Drought Severity Index (PDSI). Last modified 12 December 2019. Available online: https:/ / climatedataguide.ucar.edu/climate-data/palmer-drought-severityindex-pdsi (accessed on 31 January 2022).

20. Kosmas, C.; Ferrara, A.; Briassoulis, H.; Imeson, A. Methodology for mapping environmentally sensitive areas (ESAs) to desertification. In The Medalus Project: Mediterranean Desertification and Land Use. Manual on Key Indicators of Desertification and Mapping Environ-Mentally Sensitive Areas to Desertification; European Union Report No. 18882; Kosmas, C., Kirkby, M., Geeson, N., Eds.; European Union: Brussels, Belgium, 1999; pp. 31-47. ISBN 92-828-6349-2. 
21. Kosmas, K.; Tsara, M.; Moustakas, N.; Karavitis, C. Identification of indicators for desertification. Ann. Arid. Zones 2003, 42, 393-416.

22. Ferrara, A.; Salvati, L.; Sateriano, A.; Nolè, A. Performance evaluation and costs assessment of a key indicator system to monitor desertification vulnerability. Ecol. Indic. 2012, 23, 123-129. [CrossRef]

23. Salvati, L. From simplicity to complexity: The (changing) geography of land vulnerability to degradation in Italy. Geogr. Res. 2013, 51, 318-328. [CrossRef]

24. Basso, F.; Bove, E.; Dumontet, S.; Ferrara, A.; Pisante, M.; Quaranta, G.; Taberner, M. Evaluating Environmental Sensitivity at the basin scale through the use of Geographic Information Systems and Remote Sensed data: An example covering the Agri basin (southern Italy). Catena 2000, 40, 19-35. [CrossRef]

25. McKee, T.B.; Doesken, N.J.; Kleist, J. The relationship of drought frequency and duration of time scales. In Proceedings of the Eighth Conference on Applied Climatology, American Meteorological Society, Anaheim, CA, USA, 17-23 January 1993.

26. FAO. Report of FAO-CRIDA Expert Group Consultation on Farming System and Best Practices for Drought-Prone Areas of Asia and the Pacific Region; Food and Agricultural Organization of United Nations, Central Research Institute for Dryland Agriculture: Hyderabad, India, 2002.

27. Gumbel, E.J. Statistical forecast of droughts. Bull. Int. Assoc. Sci. Hydrol. 1963, 8, 5-23. [CrossRef]

28. Sabzevari, T. Runoff prediction in ungauged catchments using the gamma dimensionless time-area method. Arab. J. Geosci. 2017, 10, 131. [CrossRef]

29. Apollonio, C.; Bruno, M.F.; Iemmolo, G.; Molfetta, M.G.; Pellicani, R. Flood Risk Evaluation in Ungauged Coastal Areas: The Case Study of Ippocampo (Southern Italy). Water 2020, 12, 1466. [CrossRef]

30. Gioia, A.; Lioi, B.; Totaro, V.; Molfetta, M.G.; Apollonio, C.; Bisantino, T.; Iacobellis, V. Estimation of Peak Discharges under Different Rainfall Depth-Duration-Frequency Formulations. Hydrology 2021, 8, 150. [CrossRef]

31. Vojtek, M.; Petroselli, A.; Vojteková, J.; Asgharinia, S. Flood inundation mapping in small and ungauged basins: Sensitivity analysis using the EBA4SUB and HEC-RAS modeling approach. Hydrol. Res. 2019, 50, 1002-1019. [CrossRef]

32. Piscopia, R.; Petroselli, A.; Grimaldi, S. A software package for predicting design-flood hydrographs in small and ungauged basins. J. Agric. Eng. 2015, 46, 74-84. [CrossRef]

33. Onof, C.; Chandler, R.E.; Kakou, A.; Northrop, P.; Wheater, H.S.; Isham, V. Rainfall modelling using Poisson-cluster processes: A review of developments. Stoch. Environ. Res. Risk Assess. 2000, 14, 384-411. [CrossRef]

34. de Luca, D.L.; Petroselli, A.; Galasso, L. A Transient Stochastic Rainfall Generator for Climate Changes Analysis at Hydrological Scales in Central Italy. Atmosphere 2000, 11, 1292. [CrossRef]

35. de Luca, D.L.; Petroselli, A. STORAGE (STOchastic RAinfall GEnerator): A user-friendly software for generating long and high-resolution rainfall time series. Hydrology 2021, 8, 76. [CrossRef]

36. Grimaldi, S.; Petroselli, A.; Serinaldi, F. A continuous simulation model for design-hydrograph estimation in small and ungauged watersheds. Hydrol. Sci. J. 2012, 57, 1035-1051. [CrossRef]

37. Grimaldi, S.; Petroselli, A.; Serinaldi, F. Design hydrograph estimation in small and ungauged watersheds: Continuous simulation method versus event-based approach. Hydrol. Processes 2012, 26, 3124-3134. [CrossRef]

38. Grimaldi, S.; Nardi, F.; Piscopia, R.; Petroselli, A.; Apollonio, C. Continuous hydrologic modelling for design simulation in small and ungauged basins: A step forward and some tests for its practical use. J. Hydrol. 2021, 595, 125664. [CrossRef]

39. Apollonio, C.; Rose, M.D.; Fidelibus, C.; Orlanducci, L.; Spasiano, D. Water management problems in a karst flood-prone endorheic basin. Environ. Earth Sci. 2018, 77, 676. [CrossRef]

40. Ronco, P.; Zennaro, F.; Torresan, S.; Critto, A.; Santini, M.; Trabucco, A.; Zollo, A.; Galluccio, G.; Marcomini, A. A risk assessment framework for irrigated agriculture under climate change. Adv. Water Resour. 2017, 110, 562-578, ISSN 0309-1708. [CrossRef]

41. Alfio, M.R.; Balacco, G.; Parisi, A.; Totaro, V.; Fidelibus, M.D. Drought Index as Indicator of Salinization of the Salento Aquifer (Southern Italy). Water 2020, 12, 1927. [CrossRef]

42. Giordano, R.; Milella, P.; Portoghese, I.; Vurro, M.; Apollonio, C.; D’Agostino, D.; Lamaddalena, N.; Scardigno, A.; Piccinni, A.F An innovative monitoring system for sustainable management of groundwater resources: Objectives, stakeholder acceptability and implementation strategy. In Proceedings of the 2010 IEEE Workshop on Environmental Energy and Structural Monitoring Systems, Taranto, Italy, 9 September 2010; pp. 32-37.

43. Giordano, R.; D'Agostino, D.; Apollonio, C.; Lamaddalena, N.; Vurro, M. Bayesian Belief Network to support conflict analysis for groundwater protection: The case of the Apulia region. J. Environ. Manag. 2013, 115, 136-146. [CrossRef]

44. The Groundwater and the Seawater Intrusion in Apulia: From Research to the Emergency in the Safeguard of the Water Resource; Technical Periodicals for Descriptive Memories of the Geological Map of Italy; ISPRA: Rome, Italy, 2014; Volume 92.

45. Decreto del Presidente di Giunta Regionale. Agricoltura, 6 August 1992; No. 376. Available online: http://bur.regione.veneto.it/ BurvServices/Pubblica/DettaglioDecretoPGR.aspx?id=435751(accessed on 31 January 2020).

46. Council Directive 92/43/EEC of the Council of The European Communities of 21 May 1992 on the Conservation of Natural Habitats and of Wild Fauna and Flora. Available online: https:/ / eur-lex.europa.eu/legal-content/EN/TXT/?uri=celex:31992L0 043 (accessed on 11 March 2020). 
47. Piano di Tutela delle Acque della Regione Puglia 2015-2021. Available online: http://www.sit.puglia.it/portal/portale_ pianificazione_regionale/Piano\%20di\%20Tutella\%20delle\%20Acque/Documenti/PTA/PTADocumentiDownloadWindow? title $=$ Piano $\% 20$ di $\% 20$ Tutela $\% 20$ delle $\% 20$ Acque $\% 20$ - 20PTA $\% 20$ Adozione $\% 20$ proposta $\% 20 \mathrm{di} \% 20$ Aggiornamento $\% 202015-2$ 021\&piano=PTA_2019\&entity=fascicolo\&action=2 (accessed on 6 February 2022).

48. Piano di Bacino: Stralcio Assetto Idro-geologico (PAI); Relazione di piano; Autorità di bacino della Puglia (AdBP): Bari, Italy, 2004.

49. Rodriguez-Iturbe, I.; Cox, D.R.; Isham, V. Some models for rainfall based on stochastic point processes. Proc. R. Soc. Lond. Ser. A Math. Phys. Sci. 1987, 410, 269-288.

50. Cowpertwait, P.S.P. Further developments of the neyman-scott clustered point process for modeling rainfall. Water Resour. Res. 1991, 27, 1431-1438. [CrossRef]

51. ISPRA-Istituto Superiore per la Protezione e la Ricerca Ambientale. Il Clima Futuro in Italia: Analisi delle Proiezioni dei Modelli Regionali; ISPRA: Rome, Italy, 2015; Volume 58, pp. 1-64. ISBN 978-88-448-0723-8. Available online: https://www.isprambiente. gov.it/it/pubblicazioni/stato-dellambiente/il-clima-futuro-in-italia-analisi-delle-proiezioni-dei-modelli-regionali (accessed on 27 January 2022). (In Italian)

52. Koutsoyiannis, D.; Montanari, A. Negligent killing of scientific concepts: The stationarity case. Hydrol. Sci. J. 2015, 60, 1174-1183. [CrossRef]

53. Grimaldi, S.; Petroselli, A.; Romano, N. Green-Ampt Curve Number mixed procedure as an empirical tool for rainfall-runoff modelling in small and ungauged basins. Hydrol. Processes 2013, 27, 1253-1264. [CrossRef]

54. NRCS (Natural Resources Conservation Service). National Engineering Handbook-Part 630, Hydrology; U.S. Department of Agriculture: Washington, DC, USA, 2008.

55. Green, W.H.; Ampt, G.A. Studies on soil physics. J. Agric. Sci. 1911, 4, 1-24. [CrossRef]

56. Petroselli, A. A generalization of the EBA4SUB rainfall-runoff model considering surface and subsurface flow. Hydrol. Sci. J. 2020, 65, 2390-2401. [CrossRef]

57. Nalbantis, I.; Tsakiris, G. Assessment of Hydrological Drought Revisited. Water Resour. Manag. 2009, 23, 881-897. [CrossRef]

58. Singh, V.; Qin, X. Study of rainfall variabilities in Southeast Asia using long-term gridded rainfall and its substantiation through global climate indices. J. Hydrol. 2020, 585, 124320. [CrossRef]

59. Zhao, H.; Gao, G.; Yan, X.; Zhang, Q.; Hou, M.; Zhu, Y.; Tian, Z. Risk assessment of agricultural drought using the CERES-Wheat model: A case study of Henan Plain, China. Clim. Res. 2011, 50, 247-256. [CrossRef]

60. Knapp, A.K.; Carroll, C.J.; Griffin-Nolan, R.J.; Slette, I.J.; Chaves, F.A.; Baur, L.E.; Felton, A.J.; Gray, J.E.; Hoffman, A.M.; Lemoine, N.P.; et al. A reality check for climate change experiments: Do they reflect the real world? Ecology 2018, 99, 2145-2151. [CrossRef]

61. Yao, G.; Nie, Z.; Turner, N.C.; Li, F.; Gao, T.; Fang, X.; Scoffoni, C. Combined high leaf hydraulic safety and efficiency provides drought tolerance in Caragana species adapted to low mean annual precipitation. New Phytol. 2021, 229, 230-244. [CrossRef]

62. Stuart-Haëntjens, E.; De Boeck, H.; Lemoine, N.P.; Mänd, P.; Kröel-Dulay, G.; Schmidt, I.K.; Jentsch, A.; Stampfli, A.; Anderegg, W.R.; Bahn, M.; et al. Mean annual precipitation predicts primary production resistance and resilience to extreme drought. Sci. Total Environ. 2018, 636, 360-366. [CrossRef]

63. Buttafuoco, G.; Caloiero, T.; Coscarelli, R. Spatial and temporal patterns of the mean annual precipitation at decadal time scale in southern Italy (Calabria region). Theor. Appl. Climatol. 2011, 105, 431-444. [CrossRef]

64. Lionello, P.; Congedi, L.; Reale, M.; Scarascia, L.; Tanzarella, A. Sensitivity of typical Mediterranean crops to past and future evolution of seasonal temperature and precipitation in Apulia. Reg. Environ. Chang. 2014, 14, 2025-2038. [CrossRef]

65. Marini, G.; Fontana, N.; Mishra, A.K. Investigating drought in Apulia region, Italy using SPI and RDI. Theor. Appl. Climatol. 2019, 137, 383-397. [CrossRef]

66. Lopez, A.; Vurro, M. Planning agricultural wastewater reuse in southern Italy: The case of Apulia Region. Desalination 2008, 218, 164-169. [CrossRef]

67. Giordano, R.; D'Agostino, D.; Apollonio, C.; Scardigno, A.; Pagano, A.; Portoghese, I.; Lamaddalena, N.; Piccinni, A.F.; Vurro, M. Evaluating acceptability of groundwater protection measures under different agricultural policies. Agric. Water Manag. 2015, 147, 54-66, ISSN 0378-3774. [CrossRef] 